\title{
Perception of Contemporary Russian Literature in Chinese Criticism as Exemplified by the Works of Siberian Writers (V.P. Astaf'ev and V.G. Rasputin)
}

\author{
Valentina V. Nikitenko* \\ Siberian Federal University \\ 79 Svobodny, Krasnoyarsk, 660041, Russia
}

Received 12.01.2017, received in revised form 25.12.2017, accepted 15.01.2018

\begin{abstract}
Firstly, the article provides a short excursion into the history of translations and study of Russian literature in China. Furthermore, there is a brief overview of Chinese critical works within the period of 1980-2000. The article identifies the main aspects of the creative work of Siberian writers attracting the attention of Chinese researchers. The main positions of criticism, literary studies and new trends are considered. The author notes the creative interaction of Chinese writers with V.P. Astaf'ev and V.G. Rasputin, their ideological and artistic congeniality. The analysis of the material allows us to draw a conclusion about the relevance of the problems posed by Russian writers for the Chinese readers, as well as the increased attention of Chinese critics and literary historians to their work. The creative work of Siberian writers helps a Chinese reader to understand the Russian culture and the Russian mentality more deeply.
\end{abstract}

Keywords: Russian literature, translation, Chinese language, Valentin Rasputin's works, Viktor Astaf'ev's works, literary study, criticism, problems, prospects.

DOI: 10.17516/1997-1370-0211.

Research area: philology, culturology.

\section{A brief review of translations and study of Russian literature in China}

Currently, the history of development of Russian literature in China extends back more than a hundred years. It experienced a variety of stages from full imitation and worship in the early $20^{\text {th }}$ century to complete prohibition and oblivion during the Cultural Revolution (19661976).
The history of penetration of Russian classic literature into China began with A.S. Pushkin. For the first time his name was mentioned in the "Bulletin of Russian political events" published in Shanghai in 1900, and in 1903 “The Captain's Daughter" was translated into Chinese and published - it was the first publication of the Russian poet in China (Liu, Wenfei, 2004). Within a very short time, foreign translated literature took a dominant position in the Chinese

\footnotetext{
(C) Siberian Federal University. All rights reserved

* Corresponding author E-mail address: valya.nik@mail.ru
} 
book market, since in the $20^{\text {th }}$ century the works of Chinese authors mostly represented imitation of Western models.

With the beginning of the "May Fourth Movement" in 1919, Russian literature became an active participant in literary and public life in China. The first translators of the works of Russian writers were the founders of contemporary Chinese literature, such as Lu Xin. In China, after a long period of literature in the written language "Wenyan", contemporary Chinese literature in the colloquial language has been created through translations and imitation. In other words, when writing literary works in the colloquial language, the authors began with imitation of foreign literature, and a significant part of the objects of imitation was the Russian writers. The founder of contemporary Chinese literature, Lu Xin, played a huge role in popularizing Russian literature that, according to the writer's own admission, had a strong impact on his work. He highly valued the works of Russian and Soviet authors and constantly introduced them to his compatriots. According to a number of researchers, Russian classical literature had a strong impact on lives of several generations of the Chinese. Such famous authors as Pushkin, Chekhov and Gorky enjoyed wide popularity in China and are still being discovered by new readers studying Russian literature.

At the very beginning there was certain ideologization of literature, but it was not official. At that time, Russian literature was the voice of oppressed nations and was viewed by Lu Xin and other writers as an ideological weapon.

After 1949, the conditions for distribution of Russian literature in China have changed. At that time, everything was determined by the needs of ideology. Although before 1949 the quality of translations of literary works was uneven, these books are still in demand in libraries. And in the fifties of the past century most of the works of Soviet literature, including special studies of Russian literature that were translated into Chinese, were overfilled with ideology and are of little interest at present. At that time, as soon as a book was published in the former USSR, it was immediately translated into Chinese. They translated everything, and often it was far from the best literature. Even in Russia few people read protreptic books about the meaning of Soviet life. It is important to note that literature has always been regarded as an ideological weapon in socialist China. Given the political influence of the Soviet Union on the formation of a new Chinese society, the study of Russian literature in China had a clear trend towards politicization and sociologization. These trends in the study of Russian literature in China existed for quite some time. In China, a policy in the field of literature and arts was almost identical to the Soviet one. In the Soviet Union, "socialist realism" was the "only" creative method, and in China it was "revolutionary realism".

After the beginning of the "reform and opening up" in China launched in 1978, China experienced the most powerful cultural effect of other countries. According to a famous Chinese specialist in Russian philology Chen Jianhua, about 10,000 works of Russian literature were translated and published in China within this period.

As many Chinese critics believe, recently, these tendencies are much less noticeable: with the development of social democracy and implementation of the economic reform, as well as with the emergence of the new generation of translators and researchers, the study of Russian literature in China increasingly focuses on artistic and aesthetic aspects of literature, more and more attention is paid to the scientific and independent character of the literary research.

Since the 1990's, Chinese literature has changed the paradigm of development, thus 
receiving a global impulse in the context of modernism, which complicates and enriches the dialogue with Russian and world literature. At the same time, Chinese literature is increasingly recognized by the Chinese authors as part of world literature; they aspire to keep up with the writers of developed countries borrowing their creative experience.

Today, when ideology fades into the background, the development of the literary heritage appears in a completely different direction. Priority is given to aesthetic, ethical and spiritual values. A literary text appears as a means of their transmission, its purpose is to accumulate national memory, verbalize cultural meanings. In recent years, the interest of Chinese readers in modern Russian literature has increased.

At the beginning of the $21^{\text {st }}$ century the attention of Chinese researchers is attracted by such topics as rural prose, humanism in literature, literature after the collapse of the USSR - "other" prose, postmodernism and others. According to a famous Chinese literary critic, Russian philologist, translator, professor of the Nanking University Yu Yizhong, "Chinese readers have a special interest and love for Russian literature, they want to capture a spirit of the newest history of Russian people who have experienced the same stages of historical development, and to draw experience and a lesson from new Russian literature (Yu, Yizhong, 2007).

It is an interesting fact that Chinese specialists in Russian literature traditionally pay equal attention to translation and research, almost every researcher translates works of art, and almost every translator writes about Russian literature, although not everyone, of course, can prepare a serious scientific monograph. Literary translation is considered as a prerequisite and the basis of scientific work, and research is a continuation of translation and guidance for translation.
Chinese researchers have a great interest in the creative work of the Siberian writers V.G. Rasputin and V.P. Astaf'ev. Both of them became well known to Chinese readers only in the early 80's. (Chinese researchers call them classic authors of modern Russian literature, "the purest Russian writers”) (Yang, Zheng, 2014).

\section{Translations and study of the creative work of a Siberian writer V.G. Rasputin in China}

The first acquaintance of Chinese readers with the creative work of V.G. Rasputin occurred at the turn of the 1970's and 1980's: in 1978, the story "Zhivi i pomni" (Live and Remember) was published in the journal "Zarubezhnaya Literatura" (Foreign literature) (two of its translations by Li Liangshu, Ren Da'e and Feng Yidin were published almost simultaneously), and in 1980 the autobiographical story "Uroki frantsuzskogo" (French Lessons) was translated and published in the journal "Zarubezhnoe literaturnoe razvitie" (Foreign Literary Development) under the heading "Instructive stories". From the very beginning it was the moral issues of Rasputin's works that were perceived as dominant in his creative work as a whole. The literary world of the Siberian writer, who won popular recognition and love in his homeland, turned out to be interesting and close to the Chinese reader, and the high spiritual content of books is consonant with his life's problems and experiences. In my opinion, this can explain the popularity of Rasputin's stories “Den'gi dlia Marii” (Money for Maria) (1967), "Poslednii srok" (The Last Term) (1970), "Zhivi i pomni" (Live and Remember) (1974), "Pozhar" (The Fire) (1985). To date, almost all of his works are known to the Chinese reader. The study of V.G. Rasputin's creative work in China begins in the late 1970's. An editorial article entitled "The Soviet popular story - "Live and Remember" and 
its author V.G. Rasputin” was published before the publication of translations in the journal "Development of Foreign Literature" in 1977, almost at the same time when the writer was awarded the USSR State Prize.

The study of Rasputin's creative work that was distinguished, at this stage, by the significant influence of the concepts of Soviet critics and literary historians began to develop in Chinese scientific circles in the 1980's. The main attention of specialists was drawn to the story by V.G. Rasputin "Live and Remember", "Money for Maria", "The Last Term", "Proshchanie s Materoi" (Farewell to Matyora) and "The Fire". Shi Nanzhen calls Rasputin "a true master of language" and, in his article "V.G. Rasputin and his first famous work" (Shi, Nanzhen, 1981), notes that, despite the fact that the author is usually described as a writer-villager", the depth and breadth of problems of his works go far beyond the boundaries of "village". In the book "Soviet Modern Writers" Shi paid special attention to the moral themes of V.G. Rasputin's creative work, noting his deep philosophicity, psychologism, the exact recreation of Siberian color, a beautiful, rich language, lyrical principle (Shi, Nanzhen, 1982). However, Zhou Zhenmei in the article "The moral search of V.G. Rasputin" (Zhou, Zhenmei, 1991), having acknowledged seriousness of issues in the stories that concerned society, expressed an opinion that it weakened the artistic side of the works.

Analyzing "The Fire" Xu Zhenya highly appreciates realism and persuasiveness in depiction of modern reality, points out a warning nature of the work, and yet sees certain narrowmindedness of the author's position. According to the critic, "in the era of intensive transformations and the scientific and technological revolution, the writer is inclined to see the cause of social vices in derogation from tradition and, being its ardent defender, he expresses unduly sentimental feelings toward the dying village". The idea of sanctity of nature expressed in the artistic structure of the works also raises a remark about V.G. Rasputin's underestimation of the importance of the scientific progress in the use of natural resources by a man. The critic gives credit for the sincerity of the writer, notes his troublous interest in what is happening in his homeland, but the consequence of this is the increase in publicism, which affects the artistic level of the story. It should be noted that similar remarks towards the author were expressed in Soviet criticism in these years as well.

In the 1990's, the study of V.G. Rasputin's creative work, on the one hand, develops trends that have already been established, and on the other hand, after some "silence", the new works of the writer require new approaches in their study.

In the article "On the Creative work of V.G. Rasputin" Wan Peiqing makes an extensive review of the writer's creative process until the 1990's and analyzes the style development. He notes that V.G. Rasputin "reflects genuine rural life in Siberia, creates a model of the evolution of Soviet villages since the 1960 's". The theme of moral choice reflects changes in the selfconsciousness of peasants in different periods of history; the practical meaning of the story is seen in the "emotional impact on the reader contributing to the assertion of a sense of responsibility for the Motherland and the people". The charm of Rasputin novels is explained by the geniality and sincerity of the author in relation to his heroes, in describing the "inner beauty and charm" of ordinary people and especially womentoilers who are the keepers of the national spirit of Russia. A sense of confusion and an anxious sense of a crisis nature of a certain historical epoch are expressed in the works of the realistwriter. The writer again and again searches for ways of solving social conflicts and appeals to 
conscience of people prompting to recollect about moral values.

In the preface to the translation of the story "Farewell to Matyora" Shi Guoxiong notes that Rasputin's image of a woman "not only inherits the traditional features of the image of a woman of the past, but also takes into account the unique characteristics of her time" (Shi, Guoxiong). Rasputin also attaches great importance to subtle psychological characteristics. A significant role belongs to psychologism in the stories.

In connection with the political changes in the Soviet society in the second half of the 1980's - the first half of the 1990's, deeply experiencing a dramatic nature of the events, V.G. Rasputin publishes few literary works, mostly writes articles and essays. Since the mid-1990's creative inspiration has returned to V.G. Rasputin: he publishes a series of new stories, and Chinese researchers direct their attention primarily to these works. In 1996 the sixth issue of the "World Literature" journal publishes the story "Towards the same land"; in 1997 the fifth issue of the "Foreign Literature" journal publishes the story "In a hospital". In 2000 the first issue of the "Russian literature and art" journal accompanies the publication of translation of the story "The New Profession" by the article written by Ren Guangxuan "The New Rasputin is here... - a review of V.G. Rasputin's stories of recent years" (Ren, Guangxuan). The critic believes that the new works are small because the writer "squeezed" a novel into a short story and the content became "concentrated". Compared to local criticism of society in stories, the criticism in new stories is thorough and exhaustive, embracing the social system as a whole. The writer critically assesses the state of the Russian society and its interaction with the authorities. The rejection of contemporary Russian reality is the main tone and passion of the writer in the 1990's, which fully demonstrates the exceptional courage of the writer. Another theme of the writer, a relationship between a man and environment, continues and deepens in the second half of the 1990's. Ren also notes that although the writer is not actively involved in the religious revival of Russians in the 1980's and his characters rarely express religious beliefs and emotions, the writer's creative thought suddenly turns to religion in the late 1990's, religious feelings and emotions become a crucial motive in characters' life collisions, their "spiritual focus" in many cases. Meanwhile, in the second half of the 1990's, the creative horizons of the writer are also undergoing further expansion. The writer continues to pay special attention to the peasants and life in a village, but also begins to focus on the urban life of ordinary people; he is interested in changes that occur with a man who lost his habitual environment and moved from village to town. A circle of Rasputin's characters is expanding and includes people of different social strata. The fate of the intelligentsia is especially troubling for the writer. The author of the critical work concludes that "confrontation and struggle of light and dark principles, good and evil, truth and lies, beauty and ugliness, harmony and chaos in the contemporary Russian society is a constant theme of V.G. Rasputin in the second half of the 1990's".

Yang Guanghua's Doctoral thesis on the "Study of the images of V.G. Rasputin's creative work - a search for Russian national character" (Yang, Guanghua, 2003) is the first comprehensive monograph about V.G. Rasputin in China. The author believes that the most important manifestation of nationality of his works is the development of an artistic concept of a national character. Analyzing different variations of the Russian national character embodied in Rasputin's heroes, taking into account the fact that the Russian national character was historically formed as a folk and peasant, the researcher 
generalizes his observations on the figurative system and creates a typology of characters emphasizing the special significance of the image of a woman, often the old woman. Yan Guanhua traces the evolution of the "Rasputin hero" type and, noting the changes caused by the new reality, concludes that "Rasputin's images help to understand the Russian character from two sides: historical depth and modernity".

In recent years, certain results have been achieved and certain traditions have been formed in the study of V.G. Rasputin's works in China. In the new century, six monographs have already been published by Chinese researchers on the results of the study of V. Rasputin's works, five $\mathrm{PhD}$ theses have been completed (Yang Guanghua "Study of the images of V.G. Rasputin's creative work - a search for Russian national character": Doctoral thesis, Beijing, 2003, 88 p.; Zhao Yang "A concept of homeland in the works of V.G. Rasputin": Doctoral thesis, Shanghai, 2005, 115 p.; Wang Peiyin "Spiritual value orientations in the work of V. Rasputin": Doctoral thesis, Beijing, 2006, 130 p.; Shi Hongsheng "Study of the modern Russian "rural prose": Doctoral thesis, Heilongjiang, 2008, 276 p.; Ma Xiaodi “A problem of national consciousness in the works of V.G. Rasputin": PhD thesis, Moscow, 2015, 161 p.) and 16 master's theses have been dedicated to his work.

Many works are distinguished by a careful analysis, penetration into the specifics of life of another nation and a worldview. In addition to the translation work, seminars and scientific conferences are organized in China to study the work of Russian writers (a scientific and methodological seminar "Creative work of V.G. Rasputin in the context of contemporary social and spiritual problems" was held in the Russian Cultural Center in Beijing on March 24, 2012). A number of reports reflected the most important aspects of perception of his creative work in the Chinese reading and research environment.

Sun Yuhua, Wang Lidan, Liu Hong, the authors of the book titled "Study of V.G. Rasputin's Creative work", note that "V.G. Rasputin has a great influence on the Chinese literature, in particular on the work of Chinese writersvillagers: Lu Yao, Mo Yan (Nobel Prize winner in literature 2012), Jia Pingwa, Zhang Wei, Zhang Xianliang and others".

The young avant-gardist Sun Ganlu is also interested in the creative work of the traditionalist V.G. Rasputin. He shows deep respect to the Russian writer's civic position, he points out the alarming, tragic tonality of his works about modernity. Sun Ganlu draws attention to fading of the interest in traditional realistic literature in the world, as well as the reduction of translations of realist writers. In European countries, the books that create a negative image of Russia are more attractive, and they are the focus of the translators. However, in China, he claims, people appreciate real Russian literature, one of the greatest representatives of which is V.G. Rasputin. His patriotism and concern for the future of the Motherland resonate with the young Chinese prose writer: the artistic interpretation of rapid changes in life in the works of V.G. Rasputin, the results of which are often contrary to expectations and cause people's suffering, loss of their trust in the state, is seen by Sun Ganlu as continuation of the humanistic tradition of Russian literature.

In 2003, the novel "The Daughter of Ivan, the Mother of Ivan" translated by a scholarphilologist Shi Nanzheng (Rasputin, 2005) was named one of the best works of foreign authors and was awarded the "Best Foreign Novel of the $21^{\text {st }}$ Century in China" established by the publishing house "People's Literature". Chinese researchers who awarded a literary prize to the outstanding Russian writer for the latest novel "The Daughter of Ivan, the Mother of Ivan" 
were disappointed that their recognition of the gritty book was not supported and understood in Russia. It is evidence of deep understanding and compassion of the writing position in China.

The thoughts expressed by V.G. Rasputin in connection with the publication of this work in China are very significant: "The Western world that, just a while ago, set a subtle tone in literature lost it without any regret. Russia, having an exquisite and chaste taste in literature, scattered it to the winds so quickly that it did not have the $19^{\text {th }}$ century that was great in mastery and content, and then three quarters of the $20^{\text {th }}$ century" (Rasputin, 1996). Now in China, according to the writer, they print "books written in the old manner, according to the precepts and norms of those times when Tolstoy and Dostoevsky, Dickens and Faulkner, as well as Chinese Lu Xin and Lao Shi were moralizing... In China... there are at least a billion readers, and if they are all brought up on good and pure examples, mercy and diligence, beauty of nature and beauty of a human soul, a wise and profound language, by examples of love for their land and traditions - oh, there is so much in literature that is beautiful and instructive! - and if a billion of Chinese people were educated on it, and millions of Russians who did not yet fall under the rule of evil, and some of those who survived in the West, and the great East, and the rest of the world - this would be a new civilization that resolutely refused the evil in books and in all other arts! After all, we know: evil is powerful, but love and beauty are more powerful” (Rasputin, 1996).

This judgment about the current state of the world and a man, the ever-increasing importance of moral education, for which literature has always assumed responsibility, the prophetic and tragic intonation of the Russian writer testifies to his sincere love and pain for a person. Chinese readers, philologists and critics could not fail to respond to a message addressed to them.

\section{Translations and study of the creative work of a Siberian writer V.P. Astaf'ev in China}

V.P. Astaf'ev would also stand by these words. Viktor Petrovich often met with his Chinese translators, maintained active correspondence with them, he visited China and was very interested in distribution of his works in this country. His preface to the book "Zatesi" (Notches) published in 1990 (Astaf'ev, 1990) today one of the last translations of his works into Chinese - is full of disturbing reflections on the fate of Russia, the Russian people and art. He writes bitterly that the "great Chinese neighbor" that is Russia, "is struck, divided and kneeled", "where the majority of the population has lost interest in labor, where the history of the homeland is broken up, where everlasting foundations and families are destroyed, where one barely remembers his genealogy, where the life and blood of a person is devalued, faith in anything, including in God, is lost and hard to return". On the other hand, the country whose people "revere the great thinker and poet Confucius in the eighties generation, cannot be neither suppressed nor turned into a herd". Astaf'ev's and Rasputin's dissonant reflections have a 17-year age gap, but in contrast to his younger contemporary Astaf'ev believed that the country still retained the powers "capable of revival, not everywhere and not in all Russians the memory and desire for enlightenment and self-improvement is gone". "And Russian literature that is always sensitive, subtly capturing the mood of its people and the differences in its life, is constantly looking for ways of rapprochement with its readers, gaining his attention and defending the right to this attention". According to the writer's thoughts, a contemporary writer, first of all, should become the reader's interlocutor: "A person always needs an interlocutor, otherwise he will be struck with a terrible disease of the century - loneliness". 
Viktor Petrovich hoped that "among the Chinese readers there will be listeners and interlocutors. This hope is given by Great literature and Great culture of the country, in which lyrical prose and poetry, like in Russia, has always been desired by the reader" (Astaf'ev, 1990). Indeed, Victor Petrovich found grateful listeners in Chinese readers. His work is under close attention of Chinese researchers and translators.

However, it should be noted that only a few works of Astaf'ev have been translated into Chinese, such as "Pastukh i pastushka" (Shepherd and Shepherdess), "Tsar'-ryba" (Tsar-Fish), 1982 (translated by Xia Zhongyi), "Zvezdopad" (Starfall), 1985 (translated by Feng Yuli), "Pechal'nyi detektiv" (Sad Detective), 1989 (translated by Yu Yizhong), "Zatesi” (Notches), "Oda russkomu ogorodu" (Ode to the Russian Garden), 1995 (translated by Chen Shuxian, Zhang Dabeng), as well as some stories. This is undoubtedly due to the difficulties in translating Astaf'ev's works that are ambiguous and complex in language, abounding with dialectisms, occasionalisms, authorial neologisms, etc.

The first acquaintance of Chinese readers with the works of V.P. Astaf'ev happened in 1979, when the translation of two chapters "Tsar-Fish" was published in the fifth issue of the journal "Foreign Literature and Art" (Shanghai) - it was "Near the Golden Ledge" in translation of Xia Zhongyi and "Tsar-fish" in translation of Zhang Jiemei. In 1982, after publication of the translation of "Tsar-Fish" as a separate edition, Astaf'ev's name became widely known in China.

Since that time, the main works of the author have been gradually translated and published: "Shepherd and Shepherdess" (1984, Hefei; 1985, Tianjin; 1986, Changchun; 1998 Shanghai), "Starfall” (1985, Beijing), "Krazha" (Theft) (1986, Shanghai), "Sad Detective" (1988, Shanghai), "Zatesi", "Ode to the Russian Garden" (1995, Tianjin), etc. Astaf'ev miniatures are a special success among Chinese readers. For example, "Astaf'ev's Collection of Prose" in translation of the specialists in Russian philology, spouses Chen Shuxian and Zhang Dapeng, that was first published in 1995 was subsequently reprinted two more times. The last edition of 2009 was timed to coincide with the $85^{\text {th }}$ anniversary of V.P. Astaf'ev.

Why are the Chinese so fond of Astaf'ev's lyrical miniatures? As you know, Chinese culture has an unusually tight connection between poetry and painting, and in Chinese art, unlike European art, poetry, painting and calligraphy are closely related. At this, painting combines all three types of art. In the Chinese tradition, it is customary to sign paintings with lines of poetry or accompany poems with picturesque images.

Therefore, speaking of the motives for translating the "Zatesi" collection, a Russianlanguage translator, Professor Chen Shuxian, explains the interest in such works: “...One can name few works where nature is described so beautifully and poetically. By the subtlety of imagery, this is somewhat reminiscent of Chinese painting” (Konovalova, 2006); “... Paints organically merge into a beautiful picture. It seems that this is not a miniature written by a pen, but a painting, on which the marks of a brush have not dried up yet." (Chen, Shuxian, 2005), “...Astaf'ev has an original tonality. His description of nature differs by the oriental style; it's like Chinese painting that is characterized by subtlety, detalization of the depicted visible world. When translating "Zatesi" and "Ode to the Russian garden" I drew attention to the rare talent of Astaf'ev to depict plants and animals. There are about one hundred and seventy animals, birds, fish and insects described in these two works. In this living world there are more than fourteen sounds and almost twenty different colors. "Zatesi" and "Ode to the Russian garden" are like a picturesque landscape, an excellent symphony 
from the harmony of sounds and colors" (Chen, Shuxian, 2007).

As for the "Sad Detective", before the publication of this work in China, Astaf'ev's work gained universal recognition and approval, and after the Chinese translation of this, as the author himself admits, "harsh book" was published, the views of the researchers significantly divided. And when a novel "Cursed and Killed" was published in the "New World", the Chinese researchers disagreed even more. The main reason was that in these two works Astaf'ev carried out a profound reassessment and analysis of the national character, the Great Patriotic War and the Stalinist regime.

But if Astaf'ev wanted to gain the maximum degree of fame in China, it would still be his "Tsar-Fish". Just after this work Chinese critics and literary historians drew serious attention to the creative work of Astaf'ev. They devoted many articles to "Tsar-Fish" and Astaf'ev's work; he was called "a singer of nature", "a writer of morality and a poet of humanity", "an expresser of the Russian soul", "a guardian of Russian literature raising the problems of ecology" (Yang, Zheng, 2014).

In his article "Astaf'ev and China" dedicated to the $90^{\text {th }}$ anniversary of Astaf'ev a Chinese scholar Yang Zheng writes: "In "Tsar-Fish", Astaf'ev demonstrates how the destruction of Nature by a human leads to the decline of moral values, the relationship between a man and nature are a litmus test for determining the level of human morality... As the most Chinese readers note, "Tsar-Fish" is a calling card of the writer, it is his characteristic work" (Yang, Zheng, 2014).

It is not surprising that the Chinese writer Liu Xinglong considers "Tsar-Fish" to be "a classic example of description of a village", a "Village Bible" and "The Holy Scripture of a village". The writer considers Astaf'ev primarily as a lyric prose creator and a true humanist whose "imagination is always imbued with spirituality" (Liu, Xinglong, 2005). Analyzing "TsarFish", Liu Xinglong first of all notes the free composition and style of writing, which helps the author "voluntarily generalize vital facts and express their own inner experiences". The critic calls the Russian writer "a brilliant master of descriptions", in his opinion, author's reasoning combines "lyricism and philosophicity". Behind the external dissimilarity of stories in the "Narrative", Liu Xinglong saw a close internal connection conditioned by the problematics and general idea of the work: "they are all about human and nature problems that are seen in different ways from dissimilar points of view and different sides, therefore, the stories reveal a certain connection among some scattering, they organize a single global canvas - where does the world go?"

The Chinese researcher points to the symbolic significance of the stories of "Tsar-Fish". A true character of a man shows in his attitude to nature. Plundering of nature leads to "human degradation and loss of love", a change in attitude towards nature - "a path of human improvement". "Tsar-Fish" suggests disappointing reflections to Liu Xinglong: "People dream of "a cheerful and easy life", this desire goes through the ages, and our time is no exception. Therefore, a man transforms nature, controls nature, conquers nature, but at the same time people lose a lot: they lose clean air, clear water, natural delicacies, amazing landscapes, the joy of communicating with nature, they lose a peaceful atmosphere... and even beautiful feelings" (Liu, Xinglong, 2005).

The Chinese writer is well aware that the problems posed by the Russian writer are the most pressing problems of all mankind, since it is a question of the future of all flesh on Earth. In addition he calls Astaf'ev "a Russian colleague whose aesthetic trends influenced a number of 
the best modern Chinese writers". This refers primarily to the influence of "Tsar-Fish", which is rooted in the pronounced author's "boundless attachment and deep love for a village" (Liu, Xinglong, 2009).

This work had a great impact on modern Chinese literature, directly or indirectly influenced the work of a number of young Chinese writers. Such famous Chinese writers as A Lai, Mo Yan, Zhang Wei, etc. have fallen under influence of "Tsar-Fish" in their creative work and have repeatedly mentioned this work.

Of course, we cannot say that "Tsar-Fish" had only good references in China. In the chapter "Closing a book: "Tsar-Fish" after reading" of his monograph "The Pleasure of Thinking" a well-known Chinese writer Wang Xiaobo noted that the structural organization of the work raises doubts. At the beginning of the article, he enumerated many advantages of "Tsar-Fish", believing that it was an "outstanding book", and moreover he made an excellent analysis of several fragments of the work. In conclusion, he shared the moments that had raised doubts. First of all, in a story "The flying black feather", he began to doubt the author's logic: "Carefully exploring the author's logic, we notice that, apparently, extermination for the sake of living is allowed, but extermination for the sake of self-interest is forbidden".

With regard to the structure and form of the work, Wang Xiaobo also expressed his own considerations. He believes that although "TsarFish" is considered as a novel, but in fact it is a collection of novels, stories, lyrical prose and moral reasoning. Its advantage is in a big size, and a disadvantage is in the complete absence of structure" (Wang, Xiaobo, 2009).

In the new century, Chinese researchers published two monographs on the results of the study of V. Astaf'ev's creative work, wrote two PhD theses (Cao Xue "The Analysis of
"Tsar-Fish" from the position of ecofeminism": dissertations... Doctoral thesis, Jilin, 2009; Yang Zheng "The last bow" of V.P. Astaf'ev (History of Creation. Genre. Character System): PhD thesis, Moscow, 2014) and 9 master's theses devoted to his work.

\section{Conclusion}

According to Xiao Lihuan, deputy editorin-chief of the "People's Literature" publishing house, translators and editors of the publishing house attach great importance to working with contemporary authors who represent the cultural world of modern Russia. The creative work of V.G. Rasputin and V.P. Astaf'ev, the greatest Russian contemporary writers, whose works have already become classic of the $20^{\text {th }}$ century, help a Chinese reader to understand Russian culture, Russian mentality and the very Russianness better.

Virtually all the works of V.G. Rasputin have been translated into Chinese, now there are new versions of translations and the existing ones are being edited. However, in terms of mastering the rich literary heritage of V.P. Astaf'ev, it is obvious that Chinese translators still have a long way to go. Literary translation is essential for conducting a scientific work; it is its prerequisite and basis. According to the majority of Chinese researchers and translators - Chen Shuxian, Yang Zheng, Wang Zhongqi, etc. - the most effective way to overcome the lexical, grammatical and stylistic difficulties of translation is to compile a vocabulary of V.P. Astaf'ev's language, but this is still a distant future.

Thus, the prospects for studying the works of V.P. Astaf'ev and V.G. Rasputin in Chinese literary criticism are quite extensive. As we can see from the above, only a few Chinese philologists have attempted a comprehensive analysis of the legacy of V.P. Astaf'ev. The recent works (1990-2001), the writer's journalism as 
well as the creative work of V.P. Astaf'ev and V.G. Rasputin have not been thoroughly studied in the context of Russian and world literature.

The study of translations of works written by V.P. Astaf'ev and V.G. Rasputin into Chinese and the analysis of their creative work in China, in turn, provides a valuable material for a Russian researcher, allows a deeper understanding of Siberian writers and reveals common points of such unlike cultures.

\section{References}

Astaf'ev, V.P. (1990). Zatesi (Krasnoyarsk, Russia, 1990) [From the author: A foreword to publication of Zatesi book in China, Krasnoyarskii Rabochii newspaper], p. 12.

Chen, Shuxian (2005). Art features of lyrical and philosophical miniatures of Astaf'ev "Zatesi" (Krasnoyarsk, Russia) [Collected materials of the First International Scientific Conference devoted to works of Astaf'ev: Phenomenon of Astaf'ev in the socio-cultural and literary life of the late $20^{\text {th }}$ century], 43-50.

Chen, Shuxian (2007). Golos Rossii v Kitae [A voice of Russia in China]. Khabarovsk, Publishing house "Chastnaia kollektsiia", 82-83.

Konovalova, E. (2006). Kitaitsy poiut "odu russkomu ogorodu" [The Chinese sing the "Ode to the Russian garden"]. In Vechernii Krasnoiarsk.

Liu, Wenfei (2004). Perevod i izuchenie russkoi literatury v Kitae. [Translation and study of Russian literature in China], In Novoe literaturnoe obozrenie [New Literary Review], 69. Available at: http://magazines.russ.ru/nlo/2004/69/lu34.html

Liu, Xinglong (2005).“The Tzar-Fish” recreates the image of modern village. Available at: http:// www.gmw.cn/CONTENT/node_4236.htm

Liu, Xinglong (2009). Kak zhe gluboka kaplia vody [How deep is a drop of water]. Beijing, Publishing House "Writers' House", 260 p.

Rasputin, V.G. (2005). Doch' Ivana, mat' Ivana [The Daughter of Ivan, the Mother of Ivan]. Translation from Russian by Shi Nansheng. Beijing: Publishing House "Narodnaia Literatura", 244 p.

Rasputin, V.G. (1996). Chinese trap (From the Word to Chinese (and Russian) reader). Irkutsk, Russia. Available at: http://www.filgrad.ru/texts/rasputin44.htm

Ren, Guangxuan (2000). "Novyi Rasputin poiavilsia..." - obzor rasskazov V.G. Rasputina poslednikh let ["Here comes the new Rasputin..." - a review of stories by V.G. Rasputin of recent years]. In Russkaia literatura i iskusstvo [Russian literature and art], (1), 24-28.

Shi, Guoxiong (1999). Predislovie [Preface]. Rasputin V.G. Farewell to Matyora. Translation from Russian by Dong Liu. Beijing: Foreign Literature Publishers, 1-9.

Shi, Nanzhen (1981). V.G. Rasputin i ego pervoe znamenitoe proizvedenie [V.G. Rasputin and his first famous work]. In Sovetskaia literatura i iskusstvo [Soviet literature and art]. (3), 46-47.

Shi, Nanzhen (1982). V.G. Rasputin. In Sovetskie sovremennye pisateli: sbornik statei [Soviet Modern Writers: collection of articles]. Beijing: Publishing house of teaching and studying of foreign languages, 136-160.

Sun, Ganlu (2006). Vstrecha s V.G. Rasputin [Meeting with V.G. Rasputin]. In Modern weekly, (391), June 16.

Sun, Yuhua, Wang Lidan, Liu Hong (2009). Issledovanie tvorchestva V.G. Rasputina [Study of the creative work of V.G. Rasputin]. Beijing: Publishing House "Narodnaia Literatura", 225 p. 
Wan, Peiqing (1993). O tvorchestve V.G. Rasputina [On the works of V.G. Rasputin]. In Vestnik Sibeiskogo pedagogicheskogo universiteta [Bulletin of the Xibei Pedagogical University], 1, 59-64.

Wang, Xiaobo (2009). Udovol'stvie razmyshliat' [Pleasure of Thinking], Chongqing, $266 \mathrm{p}$.

Xu, Zhenya (1987). Rasteriannost' i osoznanie v pozhare - o novoi povesti V.G. Rasputina "Pozhar" [Confusion and awareness in the fire- a new story by V.G. Rasputin "The Fire"]. In Sovetskaia literatura [Modern Soviet literature], 1, 138-142.

Yang, Guanghua (2003). Issledovanie obrazov tvorchestva V.G. Rasputina - poisk russkogo natsional'nogo kharaktera [Study of the images of V.G. Rasputin's creative work - a search for the Russian national character]: Doctoral thesis, Beijing, $88 \mathrm{p}$.

Yang, Zheng (2014). Astaf'ev i Kitai - K 90-letiiu V.P. Astaf'eva. In Russian culture. 2, Nanjin University.

Yu, Yizhong (2007). Siberian sun has set (Krasnoyarsk, Russia) [Krasnoyarsky Rabochy newspaper], p. 5.

Zhou, Zhenmei (1991). Nravstvennyi poisk V.G. Rasputina [The moral search of V.G. Rasputin]. In Literatura, istoriia i filosofiia [Literature, History and Philosophy], 4, 87-92.

\section{Рецепция современной русской литературы \\ в китайской критике на примере произведений \\ писателей-сибиряков В.П. Астафьева \\ и В.Г. Распутина}

В.В. Никитенко

Сибирский федеральный университет Россия, 660041, Красноярск, пр. Свободный, 79

Статья посвящена изучению и восприятию произведений В.П. Астафьева и В.Г. Распутина в Китае. Сначала дается краткий экскурс в историю переводов и изучения русской литературы в Китае. Далее приводится краткий обзор китайских критических работ 1980-2000 годов. Выявляются основные аспекты творчества сибирских писателей, привлекающие внимание китайских исследователей. Рассматриваются основные позиции критики, литературоведения и новые тенденции. Отмечается творческое взаимодействие китайских писателей с В.П. Астафьевым и В.Г. Распутиным, идейно-художественная близость. Проведенный анализ материала позволяет сделать вывод об актуальности для китайских читателей проблем, поставленных русскими писателями, повыменном внимании китайских критиков и литературоведов $\kappa$ их творчеству. Творчество сибирских писателей помогает китайскому читателю глубже понять русскую культуру и русский менталитет.

Ключевые слова: русская литература, перевод, китайский язык, произведения В.Г. Распутина, произведения В.П. Астафьева, литературоведческое исследование, критика, проблемы, перспективы.

Научная специальность: 10.00.00 - филологические науки, 24.00.00 - культурология. 